\title{
PENGARUH PENAMBAHAN RAGI PADA MEDIA TERHADAP PERKEMBANG BIAKAN Drosophila melanogaster
}

\author{
Dian Safitri ${ }^{1}$, Suhaedir Bachtiat ${ }^{2}$ \\ ${ }^{1}$ Jurusan Pendidikan Biologi, Universitas Muhammadiyah Makassar \\ ${ }^{2}$ SMP Negeri 2 Batang, Jeneponto Sulawesi Selatan \\ E-mail: dyansafitri87@gmail.com
}

\begin{abstract}
Abstrak: Pisang mengandung asam-asam yaitu meliputi asam malat, asam sitrat dan asam oksalat. Pembuatan medium lalat buah, biasanya mengggunakan ragi atau fermifan yang berfungsi untuk menyediakan ruang udara pada medum. Berdasarkan hasil penelitian dan analisis sidik ragam, ditemukan bahwa, pengaruh ragi roti sebagai media pertumbuhan lalat buah yang dapat dilihat dari hasil rerata tertinggi pada $\mathrm{K}_{4}(3$ gr) sebesar $33,33 \%$ dan hasil rerata terkecil yaitu (0 gr) sebesar 4,6\%. Secara statistik berdasarkan perhitungan analisis sidik ragam, ada pengaruh yang signifikan bagi roti sebagai media pertumbuhan lalat buah
\end{abstract}

Kata Kunci: Lalat Buah, Fermipan, Perkembangbiakan

\section{THE INFLUENCE OF THE ADDITION OF YEAST IN A MEDIA AGAINST BODIES PROVIDE GENERATIVE Drosophila melanogaster}

\begin{abstract}
Containing banana covering malic acid, citric acid and acid oksalat. The medium of fruit flies, usually made yeast or fermifan that serves to provide space for the air at medum. Based on the research and analysis, we found that the influence of leavened bread as a medium growth of fruit flies that can be seen from the $\mathrm{K}_{4}$ on the highest ( $3 \mathrm{gr}$ ) $33,33 \%$ and results of the smallest ( 0 gr ) 4,6\%. Statistically based on the calculation of analysis, there are significant influence for bread in the growth of fruit flies
\end{abstract}

Keywords: Drosophyla, Yeast, Provide Generative

Salah satu bahan baku roti yang paling penting dalam proses pembuatan soft bread adalah ragi atau yeast. Ragi adalah mikroorganisme hidup yang berkembang biak dengan cara memakan gula. Fungsi utama ragi adalah mengembangkan adonan. Pengembangan adonan terjadi karena ragi menghasilkan gas karbondioksida $\left(\mathrm{CO}_{2}\right)$ selama fermentasi. Gas ini kemudian terperangkap dalam jaringan gluten yang menyebabkan roti bisa mengembang. Komponen lain yang terbentuk selama proses fermentasi adalah asam dan 
alkohol yang berkontribusi terhadap rasa dan aroma roti, namun alkohol akan menguap dalam proses pemanggangan roti (Haris Dwiyanto, Tanpa Tahun).

Ragi atau fermen merupakan zat yang menyebabkan fermentasi. Ragi biasanya mengandung mikroorganisme yang melakukan fermentasi dan media biakan bagi mikroorganisme tersebut. Media biakan ini dapat berbentuk butiran-butiran kecil atau cairan nutrien. Ragi umumnya digunakan dalam industri makanan untuk membuat makanan dan minuman hasil fermentasi seperti acar, tempe, tape, roti, dan bir. Adanya Fermentasi miokroorganisme pada ragi roti, mengakibatkan ragi roti banyak mengandung nutrisi yang baik bagi pertumbuhan organisme lain seperti lalat buah (Anonim, 2015).

Lalat buah adalah serangga yang berasal dari sub ordo Cyclorrapha. Secara morfologi lalat dibedakan dari nyamuk berdasarkan ukuran antenanya, lalat berantena pendek, sedangkan nyamuk berantena panjang. Lalat umumnya mempunyai sepasang sayap asli serta sepasang sayap kecil yang berguna untuk menjaga stabilitas saat ia terbang. Lalat sering hidup diantara Manusia dan sebagian jenis dapat menyebabkan penyakit yang serius.Lalat disebut penyebar penyakit karena setiap ekor lalat yang hinggap disuatu tempat maka kurang lebih 125.000 kuman yang ikut terjatuh di tempat itu. Lalat sangat mengandalkan penglihatan untuk dapat bertahan hidup. Mata majemuk yang dimiliki oleh lalat terdiri atas ribuan lensa yang sangat peka terhadap gerakan (Ani. $\mathrm{P}$, Tanpa tahun).

Lalat bermanfaat untuk dunia kesehatan, yaitu untuk terapi penyakit menggunakan larva dari lalat yang biasa disebut dengan "Maggot Therapy". Maggot Therapy atau yang biasa disebut dengan larva therapy adalah salah satu cara pengobatan alternatif untuk mengobati luka borok atau korengan yang menahun. Ketika larva tersebut sibuk menggerogoti luka ia juga sekaligus beraksi untuk membersihkan kulit mati dan daerah-daerah yang terinfeksi, membunuh bakteri yang ada dan merangsang penyembuhan atau penutupan luka.

Selain Bakteri dan Cacing tanah, lalat juga merupakan salah satu hewan pengurai yang dapat mengurai limbah rumah tangga, ini sangat penting untuk mengurangi sampah bumi.Sekelompok peneliti dari Universitas Alicante Spanyol, mengadakan penelitian yang membuktikan larva lalat dapat mengurai tinja atau kotoran dari hewan dan Manusia.Artinya larva dari lalat ini dapat dimanfaatkan mengurangi jumlah limbah biologis dimuka bumi ini.Lalat juga dapat mengurai jasad yang telah mati sehingga mudah menyatu dengan tanah (Ardiana, 2014).

Banyak pakan yang dapat digunakan untuk mengembangbiakan lalat buah, salah satunya adalah pisang. Nilai energi pisang 136 kalori untuk setiap 100 gram, namun kandungan protein dan lemak dalam pisang sangat rendah yaitu hanya 2,3 persen dan 1,3 persen. Pisang banyak mengandung mineral seperti magnesium, kalium, fosfor, kalsium dan zat besi. Kandungan vitamin dalam pisang adalah vitamin A, yaitu sekitar 0,003-1,0 mg/100 gram pisang, B, B6, C, kandungan vitamin C pada pisang meja (pisang yang siap 
dimakan tanpa diolah) adalah sekitar $10 \mathrm{mg} / 100$ gram sedangkan pisang olahan sekitar 20-25 mg/100 g buah pisang juga mengandung serotonin. Pisang juga mengandung asamasam yaitu meliputi asam malat, asam sitrat dan asam oksalat.Sewaktu pisang masih mentah asam organik utamanya adalah asam oksalat, tetapi setelah tua dan matang asam organik yang utama adalah asam malat. Sementara itu pH menurun dari 5,4 (mentah) menjadi 4,5 ketika pisang menjadi matang (Annisa. P, 2013).

\section{METODE PENELITIAN}

Jenis penelitian yang digunakan dalam penelitian ini adalah penelitian kuantitaf yang bertujuan mengetahi adanya pengaruh ragi roti sebagai media pertumbuhan lalat buah. Dengan menggunakan rancangan acak lengkap (RAL) dengan model matetatikanya seperti pada teknik analisis data. Subyek dalam penelitian ini adalah pertumbuhan lalat buah pada media. Prosedur penelitian meliputi tahapan berikut:

\section{Tahap persiapan}

a. Persiapan alat dan bahan

b. Alat yang berjenis kaca di sterilkan dengan oven

\section{Tahap pembuatan medium tumbuh}

a. Menimbang pisang $100 \mathrm{gr}$, gula merah $1 \mathrm{gr}$, dan agar-agar swallow putih $0,7 \mathrm{~g}$ serta ragi sesuai perlakuan.

b. Semua bahan dihaluskan dan dicampur dengan $100 \mathrm{ml}$ aquades steril

c. Memanaskan media selama 10 menit dan menempatkan kedalam botol selai dan ditutup dengan alumunium foil

d. Setelah media dingin diberikan ragi sesuai dengan perlakuan

\section{Tahap pengujian sampel}

a. Masukkan lalat buah kedalam botol selai masing-masing 4 ekor (2 jantan dan 2 betina).

b. Mengamati pertumbuhan lalat buah selama 2 minggu mulai dari pembentukan telur, larva, puda dan imago

c. Menghitung jumlah imago untuk setiap perlakuan dan melakukan analisis data.

Data yang diperoleh pada hasil penelitian ini berupa jumlah perkembangan lalat buah yang tumbuh pada media pertumbuhan berupa ragi. Untuk mengetahui adanya pengaruh yang signifikan dari data hasil penelitian yang diperoleh dari penelitian akan dianalisis data dengan menggunakan uji statistik one way analysis varians (ANAVA) dengan uji $\mathrm{F}$ pada taraf signifikan 5\%. Apabila pada ANAVA menunjukan perbedaan yang signifikan pada taraf 5\%, maka dilakukan uji lanjutan dengan menggunakan uji Beda Nyata Terkecil dengan taraf signifikan 5\% untuk mengetahui derajat beda antara kelompok perlakuan (Sudjana, 1992). 


\section{HASIL DAN PEMBAHASAN}

Penelitian tentang pengaruh penambahan ragi pada media terhadap perkembangbiakan imago lalat buah (Drosophila melanogaster) telah dilakukan di laboratorium Biologi Unismuh Makassar dengan hasil sebagai berikut:

Tabel 1. Pertumbuhan Lalat Buah Pad Media Perlakuan

\begin{tabular}{|c|c|c|c|c|c|}
\hline \multirow{2}{*}{ Perlakuan } & \multicolumn{3}{|c|}{ Ulangan } & \multirow{2}{*}{$\begin{array}{c}\text { Jumlah } \\
\text { (Yt) (Ekor) }\end{array}$} & \multirow{2}{*}{$\begin{array}{l}\text { Rerata } \\
\bar{Y} \text { (Ekor) }\end{array}$} \\
\hline & 1 & 2 & 3 & & \\
\hline $\mathrm{K}_{0}$ & 0 & 7 & 7 & 14 & 4,6 \\
\hline $\mathrm{K}_{1}$ & 5 & 8 & 8 & 21 & 7 \\
\hline $\mathrm{K}_{2}$ & 10 & 13 & 15 & 38 & 12,67 \\
\hline $\mathrm{K}_{3}$ & 15 & 30 & 40 & 85 & 28,33 \\
\hline $\mathrm{K}_{4}$ & 20 & 30 & 40 & 90 & 30 \\
\hline $\mathrm{K}_{5}$ & 30 & 30 & 40 & 100 & 33,33 \\
\hline \multicolumn{4}{|c|}{ TOTAL } & 348 & 19,33 \\
\hline
\end{tabular}

Data pada Tabel tersebut menunjukan adanya pengaruh ragi roti sebagai media pertumbuhan lalat buah yang ditandai dengan adanya pertumbuhan pada masing-masing perakuan, dari 6 perlakuan hasil rerata antar perlakuan secara berturut-turut dari yang terkecil sampai terbesar sebagai berikut yaitu, pada control ( 0 gr) dengan rerata 4,6 ekor, $\mathrm{K}_{1}$ (1 gr) dengan nilai rerata 7 ekor, $\mathrm{K}_{2}\left(1,5\right.$ gr) dengan nilai rerata 12,67 ekor $\mathrm{K}_{3}$ (2 gr) dengan nilai rerata 28,33 ekor, $\mathrm{K}_{4}(2,5 \mathrm{gr})$ dengan nilai rerata 30 ekor dan $\mathrm{K}_{5}(3 \mathrm{gr})$ dengan nilai rerata 33,33 ekor.

Dari data tersebut dapa dilihat bahwa dari hasil rerata tertinggi pada $\mathrm{K}_{5}$ ( 3 gr) sebesar 33,33 ekor dan yang terkecil yaiu pada control ( 0 gr) sebesar 4,6 ekor. Sehingga dapat dinyatakan bahwa pada penelitian ini ada pengaruh ragi roti sebagai media pertu,nuhan lalat buah. Analisis sidik ragam terhadap pengaruh ragi roti sebagai media pertumbuhan adalah sebagai berikut:

Tabel 2 Analisis Sidik Ragam

\begin{tabular}{|c|c|c|c|c|c|c|}
\hline $\begin{array}{c}\text { Sumber } \\
\text { Keragaman }\end{array}$ & DB & JK & KT & \multirow{2}{*}{ F $_{\text {Hitung }}$} & \multicolumn{2}{|c|}{$\mathrm{F}_{\text {Tabel }}$} \\
\cline { 1 - 4 } Perlakuan & 5 & 2407,33 & 481,47 & & & \\
\hline Galat & 12 & 225,33 & 22,53 & \multirow{2}{*}{$21,37 * *$} & 5,06 & 3,11 \\
\hline Total & 17 & 839,485 & - & & & \\
\hline
\end{tabular}

Ket. **: Berpengaruh sangat nyata

Berdasarkan pada tabel perhitungan analisis sidik ragam, terlihat terdapat pengaruh yang signifikan ragi roti sebagai media pertumbuhan lalat buah yang ditunjukan

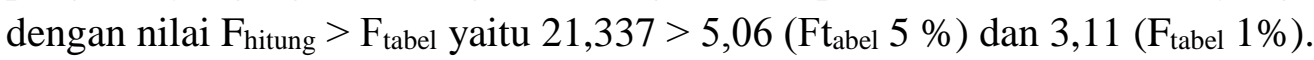


Berdasarkan hasil penelitian dan analisis sidik ragam, ditemukan bahwa, pengaruh ragi roti sebagai media pertumbuhan lalat buah yang dapat dilihat dari hasil rerata tertinggi pada $\mathrm{K}_{4}(3 \mathrm{gr})$ sebesar 33,33 dan hasil rerata terkecil yaitu ( 0 gr) sebesar 4,6. Secara statistik berdasarkan perhitungan analisis sdik ragam, ada pengaruh yang signifikan bagi roti sebagai media pertumbuhan lalat buah yang ditunjukkan dengan nilai $\mathrm{F}_{\text {hitung }}>\mathrm{F}_{\text {tabel }}$ yaitu $21,337>5,06\left(\mathrm{Ft}_{\text {abel }} 5 \%\right)$ dan 3,11 $\left(\mathrm{F}_{\text {tabel }} 1 \%\right)$. Media merupakan suatu bahan yang terdiri atas campuran nutrient. Umumnya media mengandung air, sumber energy, nitrogen, sulfur, fosfat, oksigen, hidrogen serta unsure-unsur kelumit.

Untuk pemeliharaan stok Drosophila melanogaster dapat digunakan bermacammacam medium. Medium yang dipergunakan adalah ragi digunakan sebagai bahan karena ragi mempunyai gizi sangat baik, antara lain menyediakan energi cukup tinggi. Ragi kaya mineral seperti kalium, magnesium, fosfor, besi, dan kalsium. ${ }^{21}$ Droshopilla melanogaster adalah sejenis serangga bersayap yang masuk kedalam ordo Dipteral (bangsa lalat). Sepsies ini umumnya dikenal sebagai lalat buah dalam istilah atu dalam pustaka-pustaka biologi eksperimental dan merupakan yang paling banyak digunakan dalam penelitian genetika, fisiologi, dan evolusi sejarah kehidupan.

Drosophilla melanogaster populer karena sangat mudah berkembang biak hanya memerlukan waktu dua minggu untuk menyelesaikan seluruh daur kehidupannya, mudah pemeliharaannya, serta memiliki banyak variasi fenotif yang relatif mudah diamati. Jumlah telur Drosophilla melanogaster yang dikeluarkan akan menurun apabila kekurangan makanan. Lalat buah dewasa yang kekurangan makanan akan menghasilkan larva berukuran kecil. Larva ini mampu membentuk pupa berukuran kecil, namun sering kali gagal berkembang menjadi individu dewasa. Beberapa hanya menjadi dewasa yang hanya dapat menghasilkan sedikit telur. Viabilitas dari telur-telur ini juga dapat dipengaruhi oleh jenis dan jumlah makanan yang dimakan oleh larva betina.

Pada Drosophila melanogaster dengan kondisi ideal dimana tersedia cukup ruang (tidak terlalu padat) individu dewasa dapat hidup sampai kurang lebih 40 hari. Namun apabila kondisi botol medium terlalu padat akan menyebabkan menurunnya produksi telur dan meningkatnya jumlah kematian pada individu dewasa. Intensitas Cahaya; Drosophila melanogaster lebih menyukai cahaya remang-remang dan akan mengalami pertumbuhan yang lambat selama berada di tempat yang gelap.

\section{KESIMPULAN}

1. Terdapat pengaruh ragi roti sebagai media pertumbuhan lalat buah dari hasil perhitungan sidik ragam memperlihatkan bahwa perlakuan $K_{5}$ ( 3 gr) pada ragi 3 gr/100ml memberikan pengaruh yang nyata.

2. Besarnya pengaruh yang diberikan ragi roti sebagai media pertumbuhan lalat buah adalah pada $\mathrm{K}_{5}$ (3 gr) dengan nilai rerata sebesar 33,33 ekor, dan hasil rerata terkecil yaitu (0 gr) sebesar 4,6 ekor. 


\section{SARAN}

1. Perlu adanya penelitian lebuh lanjut untuk mengetahui media pertumbuhan lain untuk pertumbuhan lalat buah.

2. Diharapkan kepada mahasiswa dalam menyelesaikan penelitian selanjutnya, dalam sebuah penelitian agar lebih paham tentang fenomena dari masalah yang diteliti sehingga mampu dipertanggung jawabkan untuk menjadi seorang sarjana.

\section{DAFTAR PUSTAKA}

Annisa Risdianika. 2013. Pengaruh Kadar Air Terhadap Tekstur Dan Warna Keripik Pisang Kepok (Musa Parasidiaca Formatypica). Skripsi. Program Studi Keteknikan Pertanian Jurusan Teknologi Pertanian Fakultas Pertanian Universitas Hasanuddin Makassar.

Anonim, Hama Yang Terdapat Pada Roti, http://repository.ipb.ac.id/bitstream/handle/123456789/53521/BAB\%20I\%20Pe ndahuluan.pdf?sequence=1, Diakses tanggal 30 April 2015.

Ani P.S. 2012. Keanekaragaman Musuh Alami Lalat Buah Pada Tanaman cabai.Jurusan Hama dan Penyakit. Skripsi. UNHAS

Ardiana. 2012. Siklus Hidup Lalat Buah. Jurusan Pendidikan Biologi Fakultas Pendidikan Matematika dan Ilmu Pengetahuan Alam Universitas Pendidikan Indonesia

Bakery Megazine.Ragi bahan Utama Pengembang Adonan, (http:// www.bakerymagazine.com/2012/02/15/ragi-bahan-utama-pengembanganadonan-roti/).Diekses Tanggal 02 November 2013Panca Rahmat. Morfologi Lalat Buah. (http ://pancarahmat. blogspot.com/2012/05 /morfologi-lalat-buahdrosophila.html0. ). Diakses Tanggal 02 November 2013

Holin Suratan Purba. 2013. Perkembangan Lalat Buah Pada Penggunaan Ubi Kayu Sebagai Bahan Dasar Pakan Buatan. Skripsi. Jurusan Hama dan Penyakit Tumbuhan, Fakultas Pertanian, Universitas Brawijaya Malang.

Masyhuri.2008. Metodologi Penelitian Pendekatan Praktis dan Aplikatif. Malang: Refika Aditama.

M. Sarjan. 2013. Kelimpahan dan Komposisi Lalat Buah Pada Lahan Kering Di Kabupaten Lombok Barat. Dinas Pertanian Tanaman Pangan Dan Holtikultura Provinsi NTB

Moore, The Mojar Groups of Falm and Their Distribution, http://fizziedotcom.blogspot.com/2008/01/manfaat-lalat-buah -dari.html. Diakses pada tanggal 12 Mei 2015.

Panca Rahmat. Morfologi Lalat Buah. (http ://pancarahmat. blogspot.com/2012/05 /morfologi-lalat-buah-drosophila.html0. ). Diakses Tanggal 02 November 2013.

Surawan Martinus. Kamus Kata Serapan. Jakarta: Gramedia Pustaka Utama. 2001. 
Semua Itu Bermanfaat. Manfaat Lalat Bauh Untuk Kehidupan Manusia. (http://semuaitubermanfaat.blogspot.com/2012/01/manfaat-lalat-untukkehidupan-manusia .html\# ixzz2k6sSUxDW0. Diakses Tanggal 02 November 2013

Scribd. Laporan Genetika Lalat Buah. (http://www.scribd.com/doc/3232 6009/LaporanGenetika-Lalat-Buah). Diakses Tanggal 02 November 2013

Rumalatu, Manfaat dan Fungsi Dari Lalat Buah, http://fizziedotcom.blogspot.com/2008/01/fungsi-dan-manaat-dari-lalat-buahdari.html. Diakses pada tanggal 12 Mei 2015.

Wikipedia. Ragi. (Http/Wikipedia/ragi). Diakses Tanggal 02 November 2013 